\title{
A Measure of Vulnerability
}

\section{Susanne van Dillen, Heidelberg}

\section{Introduction}

The vulnerability approach belongs to the various lines of work that took up and developed the ideas in SEN's (1981) classic treatise (e.g. SwIFT 1989, CURRIE 1992). Promising conceptual and empirical work has been carried out over the past two decades, but there is as yet no well-developed theory of vulnerability, and also no agreement on what are the appropriate indicators of vulnerability and how to measure them. This is a definite shortcoming of the approach as it currently stands, for it is particularly important to understand how vulnerable people can be identified and targeted (see Murdoch 1994, Henninger 1998, Maxwell 1999, PrITCHETt et al. 2000). This paper critically examines the construction of a composite index of vulnerability, which draws, in principle, upon a wide range of social indicators. The empirical application pursued here is based on extensive field research in a South Indian village in the late nineties. The problem of how to measure and weight heterogeneous variables is discussed in some detail, with special reference to SEN's (1985) position concerning the measurement of poverty, namely, that what counts is not what poor people possess, but what their possessions enable them to do. The meaning of social and spatial categories in relation to attempts to target vulnerable households will be given particular attention.

\section{Defining Household Vulnerability}

By vulnerability is meant a condition in which people face a high risk of experiencing forms of deprivation that threaten their well-being or even survival. Security, in contrast, is a condition in which this risk is low. Vulnerability and security can therefore be understood as the two extreme points on the same scale. Although vulnerability is closely connected with poverty, they are not the same thing. As normally defined, poverty is a condition in which a person or household does not have the means, legal or otherwise, to obtain a certain minimum bundle of goods, the value of which is called the poverty line. Whether a household finds itself in this state depends on the resources it possessed at the start of the period, how it chose to allocate them and whether the natural and socio-economic environment turned out to be favourable or adverse. If there is a chance that a household will experience distress at some point in time, the household is vulnerable to some degree. What is important to know, therefore, is not simply who is in distress now, but also who is at risk of being so in the future. Indicators of such inherent vulnerabilities may be found in people's ownership of resources, in their natural and socioeconomic environment, and in the course of action they take in attempting to secure their livelihoods. The vulnerability approach, therefore, disaggregates poverty and views it in the light of the mechanisms and processes that cause deprivation at present and in the future.

How does the above definition relate to the literature? Chambers (1989:1) has defined vulnerability in terms of exposure to livelihood risks and the capacity to cope with such risks. These are typically the two core components of all vulnerability frameworks, also referred to as the «external and the internal side of vulnerability» (ibid). Much weight has been placed on the examination of the external side of vulnerability (exposure) from a (low resolution) macro perspective, looking in particular at how external conditions affect endowments and limit or enhance people's coping capacity (BOHLE \& WaTTS 1993). It turned out, however, that variations in livelihood risks could not sufficiently be explained from a macro perspective alone. The sustainable livelihood securitys approaches stepped in to fill this «gap» by focussing more explicitly on the internal side of vulnerability, using a (high resolution) micro perspective, often based on (activities) and 〈assets> (Davies 1996, Carney et al. 1999). Despite a somewhat different emphasis in focus, however, the vulnerability and livelihood approaches are not separate. In the face of an ever increasing number of «different» approaches, it is therefore suggested here, following BoHLE (2001), to integrate the macro and the micro perspectives more closely than before into the existing analytic framework of vulnerability.

Geographers are naturally concerned with the spatial dimensions of social vulnerability. According to CUTTER (2001), «the vulnerability of people and places is an inherently geographical problem, one that necessitates a spatial solution». There is a long-standing debate on whether targeting should be based on social or on spatial categories, and there is in fact much empirical evidence that social vulnerability is closely connected with spatial structures and processes (RAVALLION \& Wodon 1997, Pender \& Hazell 2000). Targeting can also be based on what people actually do, and actionoriented approaches in human geography seem particularly suited to further explore this matter (WERLEN 2000). 


\section{Measuring Vulnerability: Methodological Considerations}

Given the above definition, two ways of assessing household vulnerability suggest themselves. The first takes the form of a quantitative, large-scale and longterm survey: households with different features could be observed in different settings over one or more decades. By measuring outcomes, e.g. in the form of income and consumption in each period, while recording changes in household's endowments and activity portfolios, it could be documented how frequently households with particular characteristics in particular settings experience distress, thus establishing a statistical measure of vulnerability. However, this method would not only entail an immense effort, it would also rule out the identification of vulnerable households within an acceptable time frame. Some social scientists would therefore favour another method. By investigating life histories they can reconstruct the changes in endowments and activity portfolios of different households in a particular setting over long periods of time, and in this way come to a qualitative assessment of household vulnerability. The problem here is generalisation; for identifying vulnerable households by individual in-depth assessment is not a serious option for development planners. Neither method is practicable.

The approach pursued in this article combines elements of both methods. The detailed quantitative

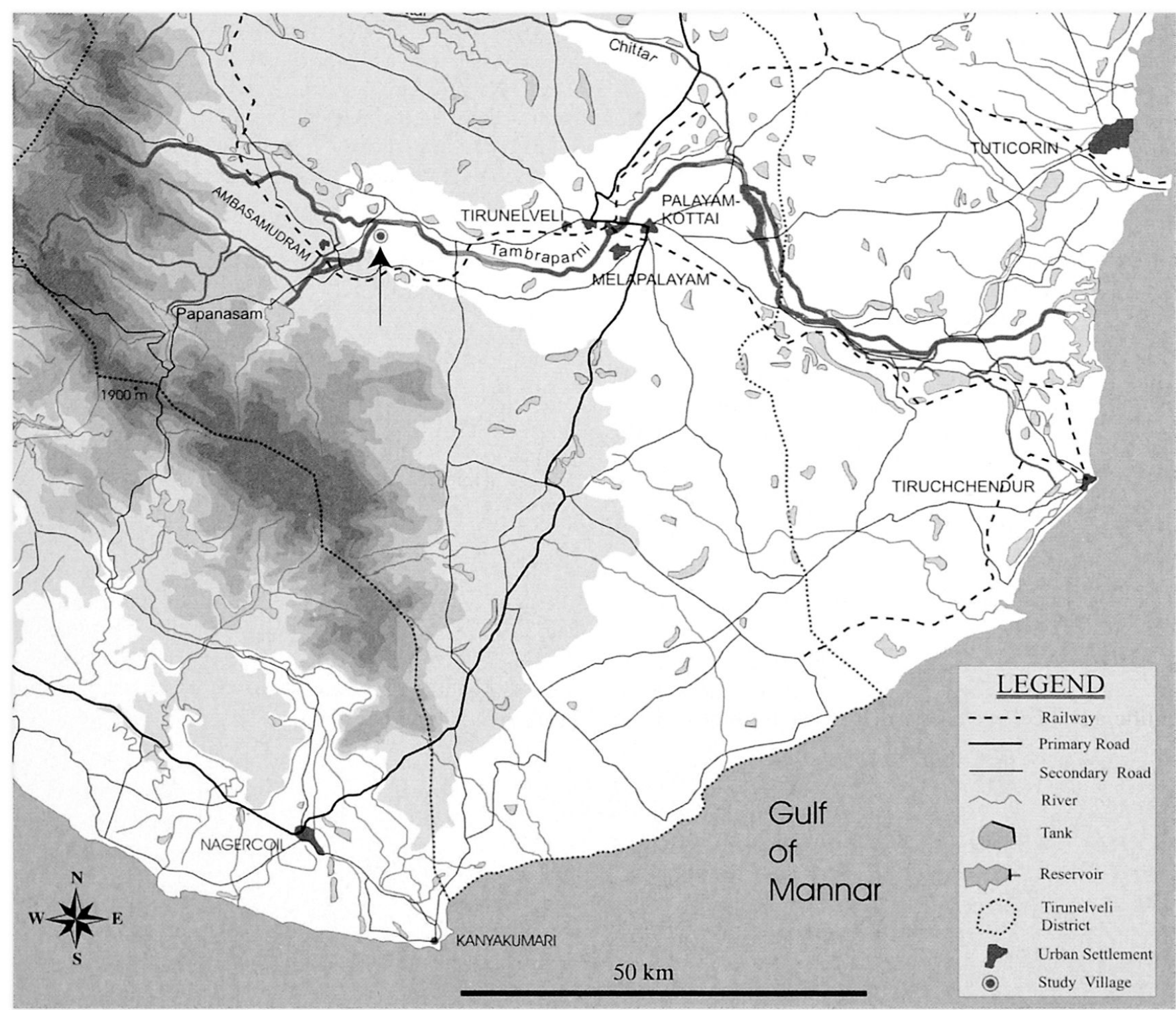

Map 1: The study region

Die Untersuchungsregion

La région étudiée

Source: based on TPC K-8C, Missouri, USA 
investigation focussed on 30 households in a study village. The range of qualitative methods included the recording of the life histories of 40 individuals. On this basis a qualitative assessment of household vulnerability was made, in the sense that the sample households were sorted into four categories with varying degrees of vulnerability. The next step was to develop a set of indicators that reflect the core determinants of household vulnerability in the study village and to construct a composite index of vulnerability. The idea is that such an index, with an equal weighting of indicators, would be valid not only in the study village, but also in comparable socio-economic settings.

\section{The Study Region}

Tirunelveli District of southern Tamil Nadu, located in a rain shadow area of the Western Ghats, has a semi-arid tropical monsoon climate. Direct precipitation is basically received between October and February, with an average annual rainfall of $888 \mathrm{~mm}$.
The Tambraparni, Tamil Nadu's southernmost perennial river, originates in the Western Ghats and flows $120 \mathrm{~km}$ south-eastward to the Gulf of Mannar, cutting through Tirunelveli and Chidambaranar districts. Its peculiar feature is that its catchment area lies well within the regime of the southwest monsoon: between June and August, when there is little or no precipitation in the south-eastern lowlands, the river runs high. The entire river basin covers an area of about $5,500 \mathrm{~km}^{2}$, but its width rarely exceeds a few $\mathrm{kms}$; it forms a narrow stripe of green in the otherwise drought-prone plains of southeast Tamil Nadu (LUDDEN 1989).

The district as a whole is classified as «backward» (Statistical Handbook of Tamil Nadu 1997). The mainstay of its economy is agriculture; the few existing large-scale industries are mainly agro- or mineral based, the most important ones being spinning and paper mills, quarrying and cement factories. There is, however, a considerable number of decentralized small scale and mostly home-based industrial units, producing items such as handmade cigarettes (beedis)

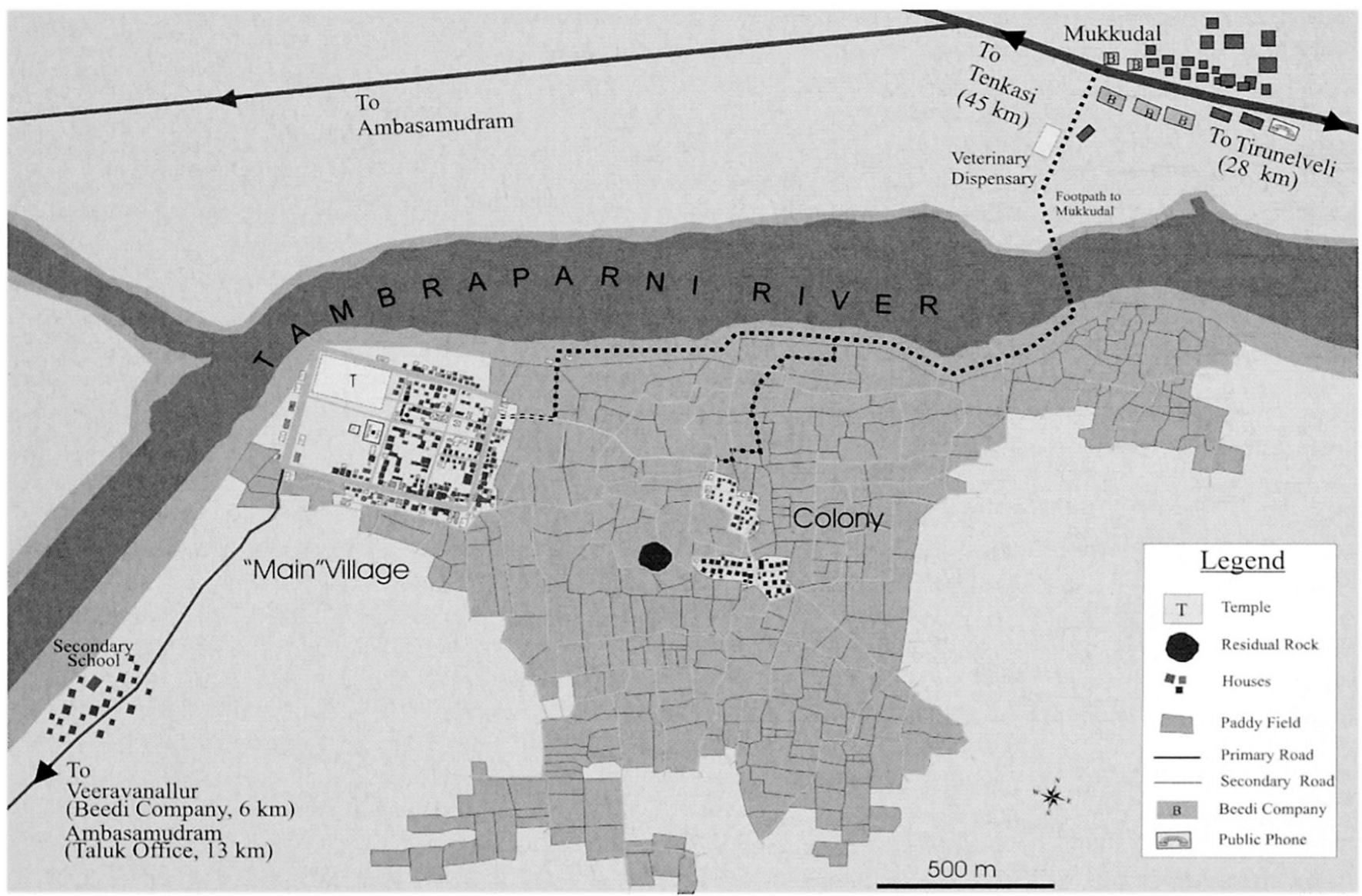

Map 2: The study village

Das Untersuchungsdorf

Le village étudié

Source: based on the land registry map, Office of the Village Administration Officer, Thaiyanallur 
and matches, which provide an important source of non-agricultural livelihood. The Tirunelveli area has a reputation for being communally tense, and clashes between «traditionally» opposed caste groups (especially the Pallar and the Maravar) are frequent. Throughout the study period (1995-1998) such events time and again virtually paralysed life in the district (Manikumar 1997, Narula 1999).

\section{The Study Village}

The village Thaiyanallur that was studied is situated in the heart of the Tambraparni river basin. Set in a river bend it is surrounded by paddy fields to the south and east. Like many other Indian villages, it is divided into two sections, the «main» village and the "colony», the latter being located $600 \mathrm{~m}$ to the west, connected by a dust road and inhabited exclusively by members of «untouchable» communities.

The «main» village with its rectangular layout and temple compound has all the features of a village that was once granted to, and inhabited by Brahmins (Tamil: brahmadeya, see STEIN 1994). During the last 50 years, however, considerable changes occurred in regard to the traditional order of caste, occupation and the distribution of wealth in the village. The Brahmins, with few exceptions, left the village after independence, and most of their land came into the hands of the dominant Maravar community. Various caste groups now inhabit the erstwhile Brahmin Street, but most of them belong to the Maravar community. Some caste groups are still concentrated in certain streets, but strict rules no longer seem to exist. Whereas interactions among different caste groups in the main village are fairly relaxed nowadays, relations between caste Hindus and members of the «untouchable» Pallar and Pariah communities, who inhabit the colony, remain traditional, «untouchability» being still a common practice in many villages of the Tirunelveli region. The infrastructure of the «main» village consists of public water taps, electricity, a primary school, a post office, a public phone, a ration shop and several grocery and tea shops. In the colony, due to a number of government housing schemes, each household now has fairly decent shelter, and most hold land titles to their housing plots. Since the early nineties, most houses have electricity, and drinking water is supplied through public taps. There is one grocery shop and a tea stall in the colony. The village is relatively well connected to the "outside world». A six-kilometre dead-end road leads from the little township of Veeravanallur to the village, with a public bus service six times a day. By walking through the fields and crossing the river towards northwest, the villagers can reach Mukkudal $(2 \mathrm{~km})$, where frequent buses run in all directions. The following table shows important characteristics of the village population categorised according to caste membership. The order of castes in this table, from left to right, gives a (disputable) idea of their traditional ritual hierarchy.

\begin{tabular}{|c|c|c|c|c|c|c|c|c|c|c|}
\hline & $B^{x^{\circ}}$ & & $4 \pi$ & & $p^{50}$ & $e^{v^{2}}$ & $\sigma^{x}$ & $e^{2}$ & evi & total \\
\hline no of households & 4 & 32 & 114 & 11 & 6 & 4 & 5 & 33 & 15 & 224 \\
\hline Average household size & 3.0 & 4.6 & 4.3 & 2.9 & 3.5 & 4.0 & 5.0 & 4.1 & 4.4 & 4.2 \\
\hline \multirow{2}{*}{$\begin{array}{l}\text { no of female-headed households } \\
\text { females per } 100 \text { males }\end{array}$} & 1 & 3 & 9 & 4 & 3 & 0 & 0 & 4 & 2 & 26 \\
\hline & \multirow[t]{2}{*}{140} & \multirow{2}{*}{101} & \multirow{2}{*}{113} & \multirow{2}{*}{113} & \multirow{2}{*}{133} & \multirow{2}{*}{128} & \multirow{2}{*}{127} & \multirow{2}{*}{90} & \multirow[t]{2}{*}{94} & 107 \\
\hline total literacy rate in percent ${ }^{a}$ & & & & & & & & & & 57 \\
\hline male literacy rate in percent ${ }^{a}$ & 100 & 85 & 77 & 64 & 87 & 67 & 25 & 43 & 70 & \\
\hline female literacy rate in percent ${ }^{a}$ & 83 & 63 & 49 & 40 & 33 & 38 & 17 & 16 & 38 & \\
\hline no of cultivating $\mathrm{HH}$ & 2 & 21 & 92 & 5 & 2 & 3 & - & 17 & 7 & 149 \\
\hline average size of holding (acre) & 0.3 & 1.9 & 2.4 & 0.5 & 0.4 & 0.9 & - & 0.7 & 0.4 & 1.8 \\
\hline
\end{tabular}

* = «untouchable» communities; a age $15+$

Table 1: Thaiyanallur - selected household characteristics (1997)

Thaiyanallur - ausgewählte Haushaltscharakteristika (1997)

Thaiyanallur - caractéristiques des ménages sélectionnés (1997)

Source: own survey 1996-1997 


\begin{tabular}{|l|ccccccc|}
\hline \multicolumn{1}{|c|}{ Caste } & farmer & $\begin{array}{c}\text { agricultural \& } \\
\text { non-agr. coolie }\end{array}$ & $\begin{array}{c}\text { skilled } \\
\text { worker }\end{array}$ & $\begin{array}{c}\text { self- } \\
\text { employed }\end{array}$ & $\begin{array}{c}\text { formal employment } \\
\text { (govt./private) }\end{array}$ & other & total \\
\hline Brahmin & - & - & - & - & 3 & 1 & $\mathbf{4}$ \\
Pillaimar & 8 & - & 3 & 5 & 11 & 5 & $\mathbf{3 2}$ \\
Maravar & 70 & 10 & 3 & 5 & 9 & 17 & $\mathbf{1 1 4}$ \\
Pandaram & 2 & - & 3 & 1 & 4 & 1 & $\mathbf{1 1}$ \\
Assari & - & 1 & 1 & - & 1 & 3 & $\mathbf{6}$ \\
Pandidar & 3 & - & 1 & - & - & - & $\mathbf{4}$ \\
Dhobi & - & - & 5 & - & - & - & $\mathbf{5}$ \\
Pallar* & 5 & 24 & - & 1 & - & 3 & $\mathbf{3 3}$ \\
Pariah* & 1 & 12 & - & - & 1 & 1 & $\mathbf{1 5}$ \\
TOTAL & $\mathbf{8 9}$ & $\mathbf{3 4}$ & $\mathbf{1 6}$ & $\mathbf{1 9}$ & $\mathbf{1 6}$ & $\mathbf{2 4}$ & $\mathbf{2 2 4}$ \\
\hline
\end{tabular}

Table 2: Primary occupation (head of household) by caste

Hauptberuf (Haushaltsvorstand) nach Kaste

Profession principale (chef de famille) selon la caste

Source: own survey 1996-1997

All the cultivable land in the study village (135 ha) is canal irrigated and very fertile. The average paddy yield is $6227 \mathrm{~kg}$ per ha during the first season (〈samba〉, Jun-Oct) and $4151 \mathrm{~kg}$ paddy per ha during the second season («pisanam), Oct-Feb). The cultivable area belongs to the village inhabitants (70 ha), to the temple trust (14 ha) and to outsiders (50 ha). Village residents operate approximately 110 ha thereof. Of the 149 households engaged in cultivation, 112 own some land, 96 operate some leased land, and 59 of the latter possess holdings of their own.

The occupational structure of the village inhabitants is set out in table 2, where it should be noted that it is often difficult to say which of an individual's various activities is "primary». Also, the (mostly male) head of the household does not always provide the main source of income. The quantitative data canvassed in the sample show e.g. that women's work in the homebased beedi industry, which was often reported as «minor» in the census, in fact sustains many a household. «Farmers` generate the larger part of their income from cultivation, be their land rented or owned. «Agricultural and non-agricultural coolies) generate the larger share of their income through wage work. 〈Skilled workers〉 are mostly skilled construction workers, but there are a few members of the service castes who still follow their traditional occupation (e.g. carpenter, washerman). «Self-employment > refers to independent, non-agricultural occupations, such as running a tea stall or grocery shop.

\section{The Sample}

Based on a census conducted in the initial phase of the fieldwork, 30 households in the village were selected for intensive study. The sample is not representative of the village population, being biased towards the «untouchables», who are clearly the most vulnerable group. There were two selection lists, one comprising colony households, the other caste Hindus. From each list, 15 households were selected at random. The following table sets out the basic characteristics of the sample so drawn (Table 3).

\section{Exploring the sSpheres of Livelihood : Indicators of Vulnerability}

The study adopted an actor-oriented approach to explore the importance of social and spatial categories in targeting vulnerable households. What are called the sspheres of livelihood are the most important activity areas identified in the study village. It should be emphasized that such sspheres h have a spatial dimension: people make their living in the material world, even if their activities are strongly shaped and constrained by social relations and processes. Indeed, many activities involve mobility. The activities of each and every household member of the sample were recorded on alternating days for the entire year July 1996 to June 1997 . They were supplemented by detailed information on mobility and income. The 


\begin{tabular}{|c|c|c|c|c|c|c|}
\hline & Maravar & Pillaimar & Pallar* & Pariah* & Pandaram & total \\
\hline no of households & 7 & 2 & 12 & 5 & 4 & 30 \\
\hline average household size & 5.3 & 4.0 & 3.8 & 4.4 & 4.5 & 4.4 \\
\hline males & 17 & 5 & 18 & 10 & 7 & 57 \\
\hline females & 14 & 3 & 20 & 8 & 8 & 53 \\
\hline no of children age $0-4$ & 6 & - & 8 & 4 & 3 & 21 \\
\hline no of female-headed households & - & - & 2 & 1 & 1 & 4 \\
\hline no of literates ${ }^{a}$ & 13 & 7 & 6 & 9 & 9 & 44 \\
\hline male literates $^{a}$ & 8 & 3 & 4 & 6 & 5 & 26 \\
\hline female literates $^{\mathrm{a}}$ & 5 & 1 & 2 & 3 & 4 & 15 \\
\hline $\begin{array}{l}\text { no of cultivating households } \\
\text { average operational holding/acre }\end{array}$ & $\begin{array}{c}6 \\
1.95\end{array}$ & - & $\begin{array}{c}5 \\
0.60\end{array}$ & $\begin{array}{c}4 \\
0.60\end{array}$ & $\begin{array}{c}2 \\
0.40\end{array}$ & $\begin{array}{c}17 \\
1.02\end{array}$ \\
\hline \multicolumn{7}{|l|}{$\begin{array}{l}\text { primary occupation } \\
\text { head of household }\end{array}$} \\
\hline farmer & 5 & - & 1 & 1 & - & 7 \\
\hline agricultural \& non-agr. coolie & 1 & - & 10 & 4 & - & 15 \\
\hline skilled worker & - & - & - & - & 2 & 2 \\
\hline self-employed & - & 2 & 1 & - & 1 & 4 \\
\hline regular employed (govt./ private) & 1 & - & - & - & 1 & 2 \\
\hline
\end{tabular}

* «untouchable» communities; ${ }^{\text {a }}$ age $15+$

Table 3: The sample households - selected characteristics

Die Haushaltsstichprobe - ausgewählte Eigenschaften

Echantillon représentatif concernant les ménages - caractéristiques sélectionnées

Source: own survey 1996-1997

activity data were then allocated among twelve categories, constituting the sspheres of livelihood, set out in table 4.

The twelve activity areas were explored with the help of both quantitative and qualitative methods (descriptive statistics, interviews, etc.). On this basis, twelve indicators were selected to form the components of a composite index of household vulnerability:

1 Caste

2 Owned land

3 Leased land

4 Livestock

5 Household compo- 11 Skills

sition: gender

6 Household compo- 12 Social integration sition: labour force

There is, of course, always an inescapable element of judgement in any such selection for the purpose of measuring well-being (UNDP 1997). The aforementioned activity areas reflect the knowledge and understanding gained in the course of long and intensive fieldwork. Each indicator can be assigned to one of the three main perspectives in vulnerability analysis. They represent aspects of socio-economic conditions (e.g. caste), endowments («assets», e.g. land, education) and action («coping», e.g. income diversification).

\section{Measuring Vulnerability: An Experimental Livelihood Security Index}

The index proposed here is developed in a specific empirical context and cannot be used in very different settings without careful modification. It will become clear, however, that the approach is quite generally applicable. For each household, each indicator is assigned an integer value in the range where minus four indicates a large contribution to vulnerability and plus four to security. All indicators are given the same 


\begin{tabular}{|c|c|c|c|c|}
\hline \multicolumn{4}{|c|}{ Occupational Activities } & \multirow{2}{*}{$\begin{array}{c}\text { Non-occupationa } \\
\text { Activities }\end{array}$} \\
\hline $\begin{array}{c}\text { Independent } \\
\text { Agricultural } \\
\text { Activities } \\
\end{array}$ & $\begin{array}{c}\text { Dependent } \\
\text { Agricultural } \\
\text { Activities } \\
\end{array}$ & $\begin{array}{c}\text { Independent } \\
\text { Non-Agricultural } \\
\text { Activities }\end{array}$ & $\begin{array}{c}\text { Dependent } \\
\text { Non-Agricultural } \\
\text { Activities }\end{array}$ & \\
\hline $\begin{array}{l}\text { - Livestock } \\
\text { - Cultivation }\end{array}$ & $\begin{array}{r}- \text { Agricultural } \\
\text { wage labour }\end{array}$ & $\begin{array}{l}\text { - Self- employ- } \\
\text { ment }\end{array}$ & $\begin{array}{l}\text { - Non-agricultural } \\
\text { wage labour } \\
\text { - Home production } \\
\text { - Regular } \\
\text { Employment }\end{array}$ & $\begin{array}{l}\text { - Reproduction } \\
\text { - Social activities } \\
\text { - Education } \\
\text { - Health } \\
\text { - Administration }\end{array}$ \\
\hline
\end{tabular}

Table 4: Activity-categories - the «spheres of livelihood Aktivitäts-Kategorien - die 'Sphären der Lebensabsicherung, Catégories d'activités - les sphères de l'assurance-protection de la vie

weight in the index, so that the (experimental) livelihood security index is defined to be

$$
\text { ELSI }=\frac{\text { sum of variable values }}{\text { number of indicators }}
$$

the number of indicators in this case being twelve. The individual indicators and the assignment of values are now taken up in detail.

\subsection{Caste}

There is hardly an activity area in which «caste does not play a meaningful role. The term is operationalised not according to the ideal of caste hierarchy, but rather according to the existing caste pecking order in this specific regional context. It is a definite disadvantage to belong to an «untouchable» community; such households are assigned the value (1), henceforth the number in brackets is the value assigned to the indicator in question. Members of the relatively low-ranked Pandaram community (2) do not, as a rule, directly compete with either ritually higher ranked communities (Pillaimar) or with the dominant Maravar. The Pillaimar (3) have the advantage of a high ritual status, which does not, however, necessarily translate into economic status inside the village. Despite their relatively low ritual status, members of the dominant Maravar community (4) are most likely to be able to act successfully in the different sspheres of livelihood.

\subsection{Owned Land}

Cultivation is the most prized source of income in the village. The value of land, however, does not result solely from the income stream generated by cultivation. Land owned serves as a security for bank loans, and it can be mortgaged and even sold in times of crisis. It was calculated that a landholding of about one acre would normally keep a household above the pov- erty line. Any property of more than one acre is thus given the highest possible value (4). Half an acre is assigned the value 3 , and smaller holdings still 2 . The value 1 is not given in this category, since even the smallest property is meaningful. The wholly landless are assigned zero.

\subsection{Leased Land}

The contribution of leased land to security depends on the type of lease contract, but such niceties were not considered here. It is rather assumed instead that the contribution of leased land basically results from the income stream generated by cultivation. The values assigned to the different holding sizes of leased land are consequently lower than those attributed to the same holding sizes of owned land. Since rents absorb up to $50 \%$ of outputs, the value 4 is assigned to a leased holding of two acres or more.

\subsection{Livestock}

Despite the problems related to the keeping of livestock in the study village, cows, buffaloes and bullocks constitute a valuable form of capital. Livestock produce a fairly secure income stream, and may serve as a buffer stock in times of crisis. The vulnerability of cattle to diseases makes them a less secure form of property than cultivable land, however, so that the highest value assigned is 3 , for at least four adult animals.

\subsection{Household Composition: Gender}

In the course of the study, it became clear that women are subject to severe discrimination. They have a narrower range of labour market opportunities, and are paid lower wage rates. Households with a high proportion of female members therefore are worse placed than those with a high proportion of males, even though the former can maintain higher standards 
in reproductive activities. The values assigned to the gender ratio are $-1,0$ and 1 , zero being given to households with equal numbers of males and females.

\subsection{Household Composition: Labour Force}

This ratio of the active to the dependent members of a household, where «active» does not necessarily mean «income generating», is evidently important. All members who contribute to a household's livelihood are counted here, including cattle herding children and older individuals. School going children and «unproductive» elder members are counted as dependants. The values assigned to this ratio are $-1,0$ and 1 , zero being given to households with an equal number of active and dependent members.

\subsection{Household Composition: Health}

Disabled and chronically ill household members often result in considerable expenditure on health. For the livelihood security of a household, however, alcoholism, which is prevalent in the village, is even worse; for often alcoholics waste not only their own earnings, but also make claims on others in the household. This variable reflects the additional costs that occur in households with chronically ill, severely disabled or alcoholic members. The values assigned are -4 to zero, depending on the number of household members falling into this category.

\subsection{Income Diversification}

The more diversified a household's income, the more resilient it is to shocks. What counts in this category is the different sources of income. Thus, if two or more household members follow the same occupation, it is counted as only one source of income. Contributions from absent household members are counted as an additional source of income, since migration is an important method of diversifying rural livelihoods. A household with five different sources of income is assumed to be quite well covered and is assigned the value 4 . Much, of course, depends on the quality of the different sources of income, an aspect that is considered in the indicator income securitys.

\subsection{Income Security}

This variable refers to all income-generating activities apart from cultivation and livestock. Among these, certain sources of income are clearly more secure than others. Though beedi work is, for example, relatively regular and partly formalized, income from this source is not classified as secure, since the sector as a whole is threatened. Beedi work is thus lumped in with casual work (i.e. agricultural and non-agricultural wage labour), and is assigned the value zero. Beedi workers «score» in the index, however, since they have particular skills (see indicator 11). Skilled work such as carpentry is assigned the value 1, a minor formal employment counts as 2 , and a minor formal employment combined with skilled work the value 3 . Full time employment in the government sector yields 4 . Absent contributing household members are also considered, because the capability to remit depends on the type and security of the livelihood of the migrant.

\subsection{Education}

Formal education is probably the most important form of human capital. Not only does it improve access to better paid jobs, but it yields also self-respect and awareness. An individual who completes his/her education beyond Standard 10 is assigned 4. An examination of the census data shows that there is a critical stage between Standard 7 and 8, in which many drop out. Thus, if at least two members complete either Standard 8,9 or 10 , the household receives the value 3 . A household in which there is only one member in this group is assigned 2. The value 1 indicates that no household member has achieved anything beyond Standard 7, and zero is reserved for households in which no member has any formal education.

\subsection{Skills}

Skills are the result of formal or informal training, such as beedi work, flower-tying or carpentry. Individuals with skills have an edge over other workers in the labour market, in respect of both opportunities and wage levels. Two members with different skills are considered a particularly important asset to a household and are assigned the value 3 .

\subsection{Social Integration}

Social capital is arguably not measurable, though there are many attempts to estimate and quantify its value (DASGUPTA 2000): none of the methods seemed to be particularly helpful here. Instead, the degree of social interaction is measured in terms of a household's timeexpenditure on 'social activities', on the grounds that the accumulated time its members spend on various forms of social interaction in the course of one year might well say something about the state of a household's network relations. The problem is that a larger time span cannot be considered. Important network nodes may be activated only once or twice in a lifetime. The variable is consequently rather crude. It should be added that (social integration' yields a common pay-off to the household. Consequently, it is not the mean time expenditure per household member that is counted, but rather the sum of all members' expenditures. Large households thus have a «competitive advantage» over smaller ones. The values assigned to this indicator emerged from an examination of household activity portfolios.

The following table summarises the complete list of indicators and the values assigned to them. 


\begin{tabular}{|c|c|c|c|c|c|c|c|}
\hline & \begin{tabular}{|c|} 
Values \\
Indicators
\end{tabular} & $\mathbf{0}$ & \multicolumn{2}{|c|}{$1(-1)$} & $2(-2)$ & $3(-3)$ & $4(-4)$ \\
\hline 1 & Caste & - & \multicolumn{2}{|c|}{ Pallar, Pariah } & Pandaram & Pillaimar & Maravar \\
\hline 2 & $\begin{array}{l}\text { Owned } \\
\text { land }\end{array}$ & No land property & \multicolumn{2}{|c|}{-} & $0.01-0.50$ acres & $0.51-0.99$ acres & 1 acre + \\
\hline 3 & Leased land & No leased land & \multicolumn{2}{|c|}{$0.01-0.50$ acres } & $0.51-0.99$ acres & $1.00-1.99$ acres & 2 acres + \\
\hline 4 & Livestock & No cattle & \multicolumn{2}{|c|}{$\begin{array}{c}1-2 \\
\text { cows/bullocks }\end{array}$} & $\begin{array}{c}\text { 3-4 } \\
\text { cows/bullocks }\end{array}$ & $\begin{array}{c}+ \\
\text { cows/bullocks } \\
\end{array}$ & - \\
\hline 5 & $\begin{array}{l}\text { Household } \\
\text { composition: } \\
\text { gender }\end{array}$ & $\begin{array}{c}\text { Equal number of } \\
\text { female and male } \\
\text { members }\end{array}$ & $\begin{array}{c}\text { More } \\
\text { female } \\
\text { members }\end{array}$ & $\begin{array}{c}\text { More } \\
\text { male } \\
\text { members }\end{array}$ & - & - & - \\
\hline 6 & $\begin{array}{l}\text { Household } \\
\text { composition: } \\
\text { labour force }\end{array}$ & \begin{tabular}{|l|} 
Equal number of \\
active and \\
dependent \\
members
\end{tabular} & $\begin{array}{c}\text { More } \\
\text { dependent } \\
\text { members }\end{array}$ & $\begin{array}{c}\text { More } \\
\text { active } \\
\text { members }\end{array}$ & - & - & - \\
\hline 7 & $\begin{array}{l}\text { Household } \\
\text { composition: } \\
\text { health }\end{array}$ & - & \multicolumn{2}{|c|}{$\begin{array}{l}\text { One chronically ill or } \\
\text { alcoholic household } \\
\text { member }\end{array}$} & $\begin{array}{c}\text { Two } \\
\text { chronically ill } \\
\text { or alcoholic } \\
\text { household } \\
\text { members }\end{array}$ & $\begin{array}{c}\text { Three } \\
\text { chronically ill } \\
\text { or alcoholic } \\
\text { household } \\
\text { members }\end{array}$ & $\begin{array}{c}\text { Four } \\
\text { chronically } \\
\text { ill or } \\
\text { alcoholic } \\
\text { household } \\
\text { members }\end{array}$ \\
\hline 8 & $\begin{array}{l}\text { Income di- } \\
\text { versification }\end{array}$ & $\begin{array}{l}\text { One source of } \\
\text { income }\end{array}$ & \multicolumn{2}{|c|}{$\begin{array}{c}\text { Two different sources } \\
\text { of income }\end{array}$} & $\begin{array}{c}\text { Three different } \\
\text { sources of } \\
\text { income }\end{array}$ & $\begin{array}{c}\text { Four different } \\
\text { sources of } \\
\text { income }\end{array}$ & $\begin{array}{l}\text { Five diffe- } \\
\text { rent sources } \\
\text { of income } \\
\end{array}$ \\
\hline 9 & $\begin{array}{c}\text { Income } \\
\text { security } \\
\text { (non-agricul- } \\
\text { tural income) }\end{array}$ & $\begin{array}{c}\text { Income only } \\
\text { from unskilled } \\
\text { casual work, } \\
\text { unskilled self- } \\
\text { employment and } \\
\text { beedi work } \\
\end{array}$ & \multicolumn{2}{|c|}{$\begin{array}{l}\text { At least one income } \\
\text { from skilled work, or } \\
\text { self-employment based } \\
\text { on skilled work }\end{array}$} & $\begin{array}{c}\text { At least one } \\
\text { minor formal } \\
\text { employment } \\
\text { (govt, private) }\end{array}$ & $\begin{array}{l}\text { At least one } \\
\text { full time } \\
\text { formal } \\
\text { employment } \\
\text { (private) }\end{array}$ & $\begin{array}{l}\text { At least one } \\
\text { full time } \\
\text { formal } \\
\text { employment } \\
\text { (govt) }\end{array}$ \\
\hline 10 & Education & $\begin{array}{l}\text { No member has } \\
\text { any formal } \\
\text { education }\end{array}$ & \multicolumn{2}{|c|}{$\begin{array}{l}\text { No member aged } 14+ \\
\text { studied beyond } \\
\text { Standard } 7\end{array}$} & $\begin{array}{l}\text { At least one } \\
\text { member } \\
\text { completed } \\
\text { Standard } 8,9 \\
\text { or } 10\end{array}$ & $\begin{array}{l}\text { At least two } \\
\text { members } \\
\text { completed } \\
\text { Standard } 8,9 \\
\text { or } 10\end{array}$ & $\begin{array}{l}\text { At least one } \\
\text { member } \\
\text { achieved } \\
\text { higher than } \\
\text { Standard } 10\end{array}$ \\
\hline 11 & Skills & - & \multicolumn{2}{|c|}{ Ordinary skills } & $\begin{array}{l}\text { At least one } \\
\text { member has } \\
\text { skills }\end{array}$ & $\begin{array}{c}\text { At least two } \\
\text { members have } \\
\text { different skills }\end{array}$ & $\begin{array}{c}\text { At least } \\
\text { three mem- } \\
\text { bers have } \\
\text { different } \\
\text { skills }\end{array}$ \\
\hline 12 & $\begin{array}{c}\text { Social } \\
\text { integration }\end{array}$ & - & \multicolumn{2}{|c|}{$\begin{array}{c}160-399 \text { hours spent } \\
\text { on social activities }\end{array}$} & $\begin{array}{c}400-799 \\
\text { hours spent on } \\
\text { social } \\
\text { activities }\end{array}$ & \begin{tabular}{|c|}
$800-1,199$ \\
hours spent on \\
social \\
activities
\end{tabular} & $\begin{array}{c}1,200+ \\
\text { hours spent } \\
\text { on social } \\
\text { activities }\end{array}$ \\
\hline
\end{tabular}

Table 5: The index key and assigned values (highlighted cells indicate negative values)

Index-Schlïssel und-Werte (die hellgrauen Zellen zeigen negative Werte an)

Barème des indices et valeurs (les zones en gris clair indiquent des valeurs négatives) 


\section{Household Vulnerability Assessments and the ELSI}

Given the selection of indicators and the values assigned to them in table 5 , we obtain the values of the ELSI reported in table 6, where households are ranked in ascending order. The mean value of the index is 1.06 , with a standard deviation of 0.39 . The distribution is fairly symmetric, with a median value of 1.00 .

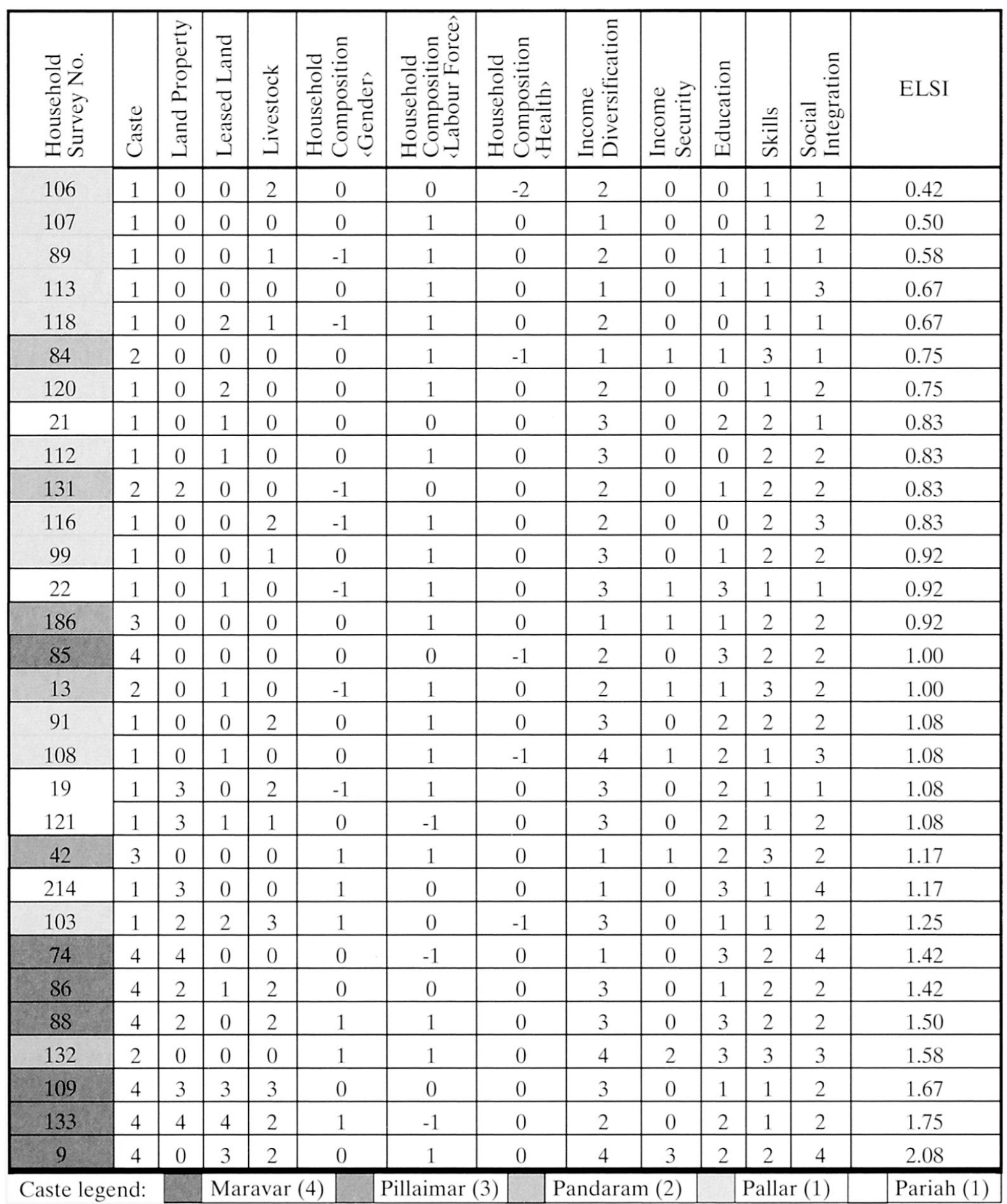

Table 6: The «experimental livelihood security index» applied to the sample $(n=30)$

Der "experimentelle Lebensabsicherungs-Index", angewendet auf die Haushaltsstichprobe ( $n=30)$

Barème "expérimental des indices de l'assurance-vie» appliqué à l'échantillon représentatif $(n=30)$ 


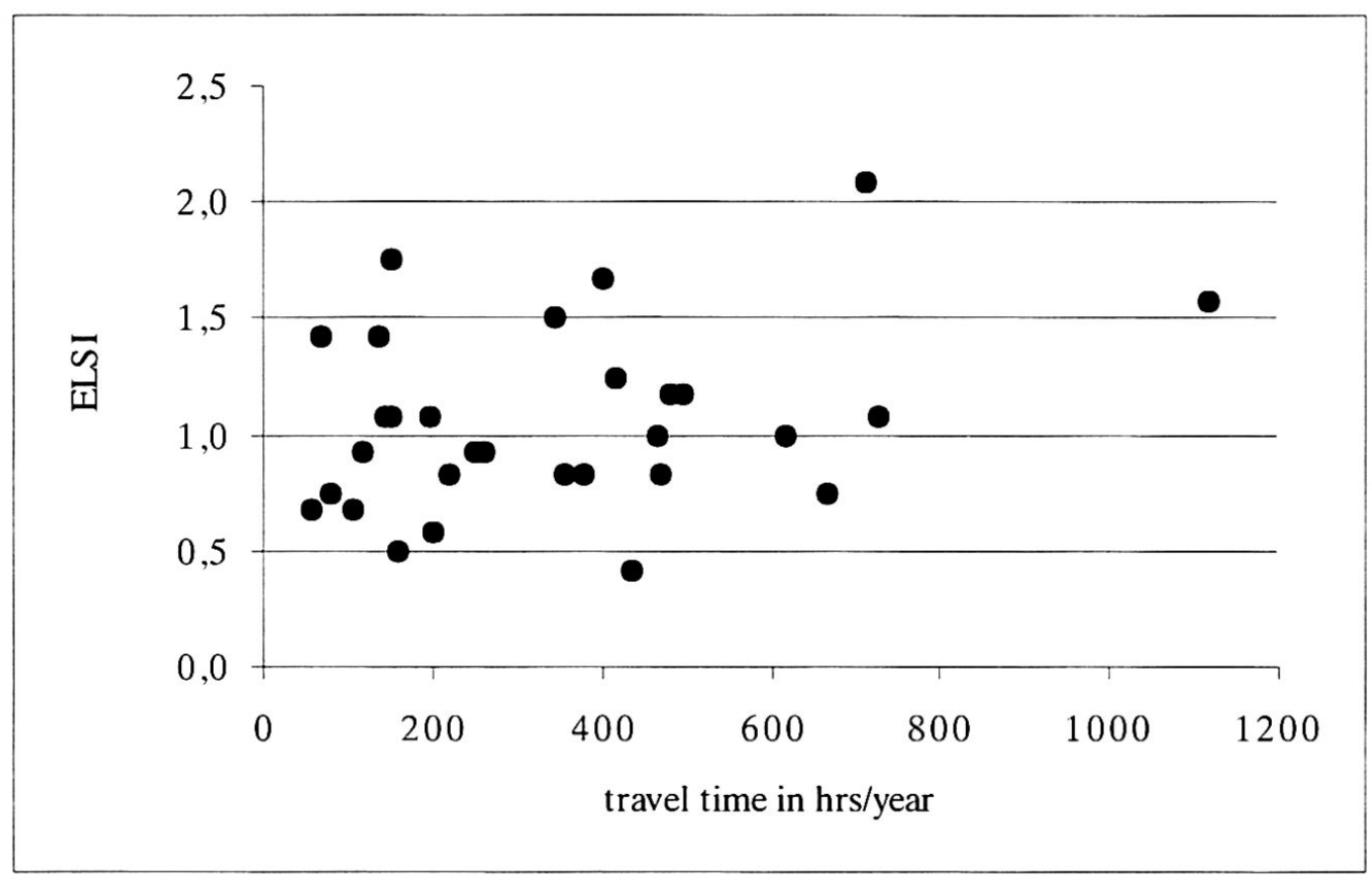

Fig. 1: Scatterplot of ELSI and total travel time in hours Streudiagramm, ELSI vs. gesamte Reisezeit in Stunden Diagramme graphique ELSI et durée totale du voyage en heures

As expected, the index is strongly associated with caste. Households belonging to the dominant Maravar community are concentrated at the upper end of the security scale whereas those belonging to the «untouchable» Pallar and Pariah communities make up the great majority of the group lying below the median value of 1.00 . That three of the five Pariah households rank higher than the median, is explained by their long-established migrant networks, their educational achievements and superior income-earning strategies. Landholdings are strongly correlated with household security, but also with caste. Yet a land-less Pandaram household (No. 132) attains a high score through its educational achievements, a favourable household composition and a well-chosen income portfolio. To sum up, when compared to the qualitative assessment of household vulnerability made at an earlier point of the study, the ELSI yields a reliable picture of the situation. The use of socio-economic variables such as 'caste), 〈occupation and landholding) alone results in very different and - from the vulnerability point of view - misleading assessments. With this much established, we now examine how ractivity portfolio, <mobility and particularly the ex-post (outcome) variable incomes relate to the index.

\section{Activity Portfolios as an Indicator of Household Vulnerability}

It is noteworthy that both among the most vulnerable and among the most secure households, activity (and income) portfolios are little diversified (REARDON et al. 2000). Similarly, statistical analysis of the activity data shows that there is little correlation between time expenditure on non-occupational activity categories - such as (reproduction) and (social activities) - and household security or vulnerability. As for income generating activities, households with large time expenditure in the activity agricultural wage labour tend to be vulnerable, whereas a large share of time spent on (cultivation) goes with security, as does any combination with «regular employments in the formal sector. Beedi work is an important source of non-agricultural household income, and in combination with cultivation and livestock keeping, or with skilled non-agricultural wage labour, can often be found in households assessed as moderately secure. With these few exceptions, however, the data do not support the claim that specific activity portfolios are typically associated with either vulnerability or security (SCOONES 1998, ELLIS 2000). Activity portfolios do not, as some argue, stand exclusively for the internal side of vulnerability («coping)). They depend to a considerable extent on other components of the ELSI, some of which can be seen as external (e.g. caste and land property), while others clearly contain elements of choice, or «coping). The study reveals that households with similar activity portfolios may have very different motivations, and so display different degrees of vulnerability. Activity portfolios as such are very imperfect indicators of vulnerability. 


\section{Mobility as a Spatial Expression of Social Vulnerability}

There are no specific micro-mobility patterns associated with the security or the vulnerability of households in the sample group. This holds not only when mobility patterns are differentiated according to activity areas, but also in regard to aggregated mobility at the household level. Figure 1 shows that the correlation between aggregate household travel time and the ELSI is not strong (Pearson's $r=0.31$ ).

\section{Income as a Measure of Vulnerability}

Income is generated in the seven occupational activity areas (see table 4). Figure 2 reveals that the correlation between per capita income and ELSI in the sample group is wholly insignificant (Pearson's $r=0.045$ ). The income realized by the two highest-ranked households according to the ELSI (triangular data points, figure 2 ), is not high in an absolute sense. The households are well-diversified, however, and in both cases, a part of their income results from employment in the formal sector. Also, there are households assessed as vulnerable although they had relatively high incomes in the study period.

All these findings support the view that income , as an outcome variable, is only a crude indicator of vulnerability. It is the assessment of detailed information that reveals the hidden vulnerabilities that make households susceptible to income failure.

\section{Discussion}

The vulnerability approach is based on the idea that a combination of different research perspectives improves our understanding of the causes of vulnerability. If one wants to measure vulnerability, therefore, the use of multiple indicators and the construction of composite indices seem to be the next logical step. The study shows that the selection of appropriate indicators of household vulnerability is possible in a particular setting, and that the considerations involved are generally applicable. Where detailed information from other studies is available, it is relatively simple to compile an appropriate set of indicators fairly quickly. There remains the difficulty that the indicators derived from the vulnerability framework are drawn from entirely different analytic categories. Any attempt to measure vulnerability in the form of a composite index is therefore faced with serious methodological problems: how the indicators should be weighted relative to another is completely left open in the vulnerability framework. Such relative weights depend heavily on the specific circumstances in a locality. 〈Caste〉, for example, is important throughout India, and would therefore always be an important variable. The meaning of the variable 〈caste> (and thus its weight), however, may be different in other villages located close to Thaiyanallur.

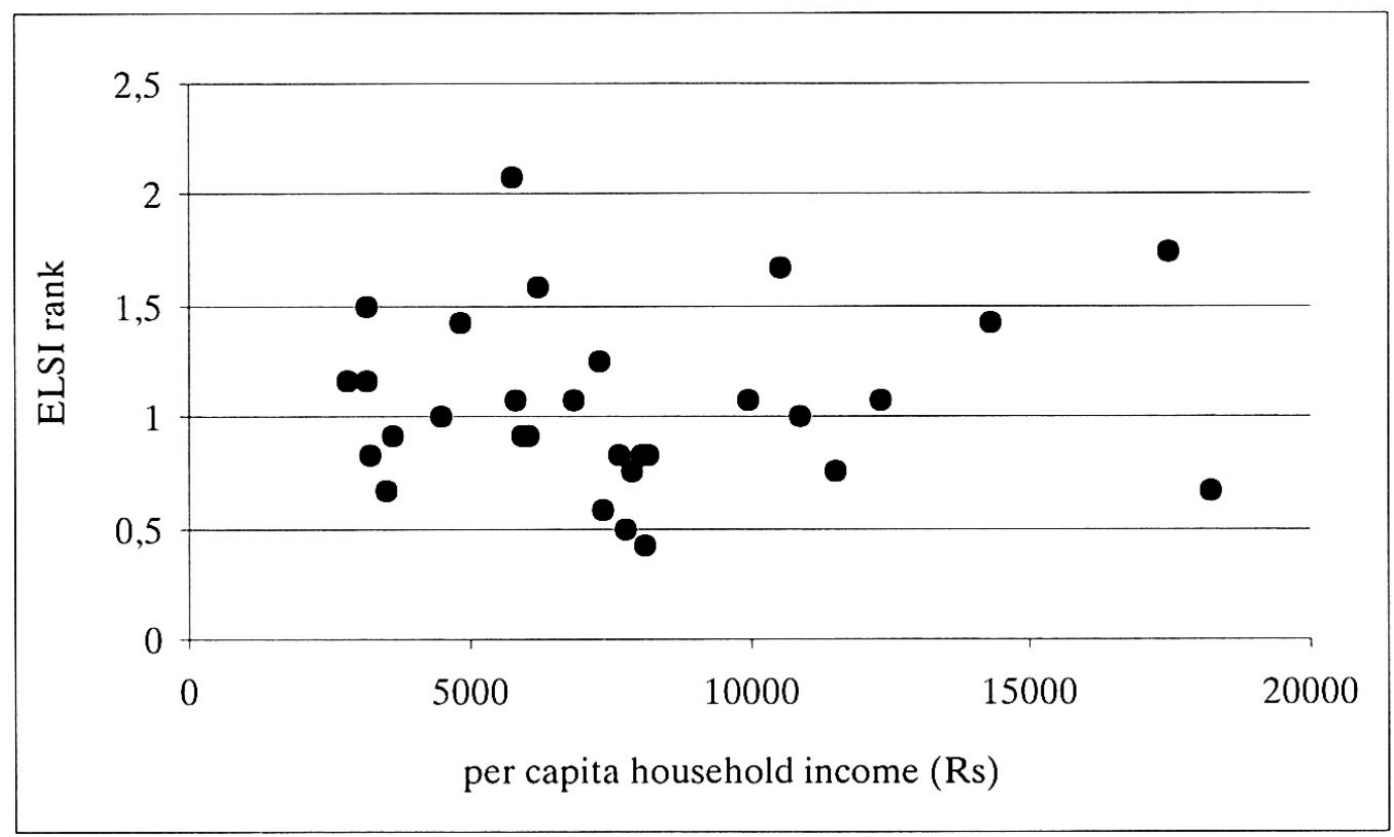

Fig. 2: Scatterplot of ELSI and per capita household income 
As for the use of social and/or spatial categories in targeting vulnerable households, it is clear that differences in vulnerability are much more strongly connected to social than spatial categories. It is, moreover, methodologically incorrect to construct causalities from the spatial to the social when assessing whether a household is vulnerable. Members of households belonging to «untouchable» communities, for example, live in the colony. What makes them vulnerable, first of all, is not that they live there, but rather their caste affiliation and the stigmatisation attached to it. Also, not all inhabitants of the colony are equally vulnerable: households belonging to the Pariah community are, as a rule, more secure than Pallar households, due to their superior income-earning strategies and network relations. A central conclusion to be drawn from this study, therefore, is that vulnerability assessment at the sub-district level (e.g. in the context of project implementation and evaluation) is only promising when based on social categories. Vulnerability assessment on a larger spatial scale, however, would surely require the extensive use of spatial categories, since there are «critical regions» as well as «vulnerable people» (KASPERSON et al. 1995).

\section{References}

BoHLE, H.-G. (2001): Vulnerability and criticality. Perspectives from social geography. - In: IHDP Update, Newsletter of the International Human Dimension Programme on Global Environmental Change (IHDP) No. 2: 1-4.

Bohle, H.-G. \& M. WattTs (1993): Hunger, famine and the space of vulnerability. - In: GeoJournal 30 (2): 117-125.

Carney, D., Drinkwater, M., Rusinow, T., Neefjes, K., Wanmali, S. \& N. Singh (1999): Livelihood approaches compared. A brief comparison of the livelihood approaches of the UK Department for International Development (DFID), CARE, Oxfam and the United Nations Development Programme (UNDP). London: Department of International Development. Chambers, R. (1989): Vulnerability, coping and policy. - In: Institute of Development Studies (IDS) Bulletin, $20(2): 1-7$.

CuRrie, B. (1992): Food crises and prevention. An analysis in the Indian context. - In: Contemporary South Asia 1 (1): 93-111.

CUTTER, S.L. (2001): A research agenda for vulnerability science and environmental hazards. - IHDP Update, Newsletter of the International Human Dimension Programme on Global Environmental Change (IHDP) No. 2: 8-9.

DASGUPTA, P. (2000): Economic progress and the idea of social capital. - In: Dasgupta, P. \& I. Serageldin (eds): Social capital, a multifaceted perspective. -Washington.
Davies, S. (1996): Adaptable Livelihoods. Coping with Food Insecurity in the Malian Sahel. - London et al.: MacMillan.

Ellis, F. (2000): Rural livelihoods and diversity in developing countries. - Oxford, New York: Oxford University Press.

HENNINGER, N. (1998): Mapping and geographical analysis of human welfare and poverty. Review and assessment. - Washington: World Resources Institute.

Kasperson, R.E., Kasperson, J.X. \& B.L. Turner (1995): Regions at risk. Comparisons of threatened environments. - Tokyo, New York, Paris: United Nations University Press.

Ludden, D. (1989): Peasant history in South India. Oxford, Madras: Oxford University Press.

Manikumar, K.A. (1997): Caste Clashes in South Tamil Nadu. - In: Economic and Political Weekly, September 6: 2242-2243.

MAXWELL, S. (1999): The meaning and measurement of poverty.-ODI Poverty Briefing (http://www.odi.org.uk/ briefing/pov3.html).

MuRdOCH, J. (1994): Poverty and vulnerability. - In: AEA Papers and Proceedings 84 (2): 221-225.

NARULA, S. (1999): Broken people. Caste violence against India's «untouchables». - New York et al.: Human Rights Watch.

Pender, J. \& P. Hazell (2000): Promoting sustainable development in less-favoured areas. - International Food Policy Research Institute (IFPRI), Washington.

Pritchett, L., Suryahadi, A. \& S. Sumarto (2000): Quantifying vulnerability to poverty. A proposed measure, applied to Indonesia. - World Bank Policy Research Paper No. 2437, Washington.

Ravallion, M. \& Q. Wodon (1997): Poor areas, or only poor people? - The World Bank, Policy Research Working Paper 1798. - Washington.

Reardon, T., Taylor, J.E., Stamoulis, K., Lanjouw, P. \& A. Balisacan (2000): Effects of non-farm employment on rural income inequality in developing countries. An investment perspective. - In: Journal of Agricultural Economics 51 (2): 266-288.

Scoones, I. (1998): Sustainable rural livelihoods. A framework for analysis. - Institute of Development Studies (IDS), Working Paper No. 72.

SEN, A.K. (1981): Poverty and famines. An essay on entitlement and deprivation. - Oxford: Clarendon Press.

SEN, A.K. (1985): Commodities and capabilities. Amsterdam, New York, Oford: North-Holland.

Statistical Handbook of Tamil Nadu (1997). - Directorate of Economics and Statistics, Chennai.

Stein, B. (1994): Peasant State and Society in Medieval South India. - New York, Madras: Oxford University Press.

Swift, J. (1989): Why are rural people vulnerable to famine? - In: Institute of Development Studies (IDS) Bulletin 20 (2): 49-57. 
UNDP (United Nations Development Programme) (1997): Human Development Report 1997. - New York.

WeRLen, B. (2000): Sozialgeographie. - Bern, Stuttgart, Wien: Paul Haupt.

\section{Summary: A Measure of Vulnerability}

The article, based on an extensive field study carried out from 1995-1998 in a South Indian village, is concerned with the question of how vulnerable people can be identified and targeted. By focusing on the most important activity areas in the study village, i.e. on what people actually do, it is possible to see how social and spatial processes are tied up with each other. In the light of the fieldwork, a quantitative index of vulnerability is proposed. The purpose of this index is to measure the vulnerability of households in this particular setting, or at least to rank them according to their vulnerability. In keeping with the conceptual approach the index is not based on observed outcomes in the forms of incomes realised during the study period. Rather, by taking a close look at how such outcomes were achieved, it seeks to identify the core determinants of vulnerability which lay hidden in the complex social and spatial processes of everyday life in the study village. Under clearly defined conditions such indices may be helpful in targeting vulnerable groups. They are problematic with regard to both concept and method, however, in particular when applied in larger spatial and social contexts.

\section{Zusammenfassung: Ein Maß der Verwundbarkeit}

Der Artikel beschäftigt sich auf der Grundlage einer umfangreichen Dorfstudie in Südindien aus der zweiten Hälfte der 90er Jahre mit den Fragen, wie sich verwundbare Gruppen identifizieren lassen und welche Bedeutung räumlichen und gesellschaftlichen Kategorien in diesem Zusammenhang zukommt. Basierend auf einer Analyse der zentralen Handlungsbereiche der Menschen in einem südindischen Dorf wird ein zusammengesetzter, quantitativer Index vorgeschlagen, der die Verwundbarkeit von Haushalten in einem spezifischen regionalen Kontext misst, bzw. diese Haushalte entsprechend ihrer Verwundbarkeit relativ zueinander anordnet. Dem gewählten konzeptionellen Ansatz entsprechend setzt sich der Index nicht aus Ergebnisvariablen wie z.B. dem Haushaltseinkommen oder bestimmten Konsumparametern zusammen, sondern ermittelt mit Hilfe verschiedener Indikatoren, wie diese Ergebnisse erzielt wurden, d.h. welche Haus- halte auch in der Zukunft mit hoher Wahrscheinlichkeit krisenanfällig bzw. gesichert sind. Unter klar definierten Bedingungen können solche Indizes für die Identifikation verwundbarer Gruppen durchaus nützlich sein. Sie sind jedoch konzeptionell und methodisch grundsätzlich problematisch, was besonders bei der Anwendung in größeren räumlichen und gesellschaftlichen Kontexten deutlich wird.

\section{Résumé: Une mesure de la vulnérabilité}

Cet article se base sur l'étude approfondie d'un village dans le Sud de l'Inde dans les années 90 et pose la question de savoir comment identifier les groupes vulnérables et quelle est l'importance à donner aux catégories géographiques et sociales. Selon une analyse des domaines d'action principaux des habitants d'un village dans le Sud de l'Inde, nous avons établi un barème d'indices qui permet de mesurer la vulnérabilité des ménages dans un contexte régional spécifique ou même de classer ces ménages selon leur vulnérabilité. Nous avons choisi de ne pas faire entrer dans ce barème de simples variables tel le revenu des ménages ou certains paramètres de consommation, mais plutôt d'indiquer comment on en est arrivé à ces résultats à l'aide de différents indicateurs, c'est-à-dire quels seront les ménages certainement vulnérables à l'avenir ou quels sont ceux qui ne le seront pas. Une fois bien définis, de tels indices peuvent être utiles pour identifier les groupes vulnérables. Leur utilisation n'est cependant pas sans problèmes surtout si l'on veut les appliquer à un contexte social et géographique plus important.

Dr. Susanne van Dillen, Südasieninstitut der Universität Heidelberg, Abteilung Geographie, Im Neuenheimer Feld 330, D-69120 Heidelberg.

e-mail: vandillen@urz.uni-heidelberg.de

\section{Manuskripteingang/received/manuscrit entré le} 21.9.2001

Annahme zum Druck/accepted for publication/accepté pour l'impression: 25.2.2002 